\section{HeGEL, A MORTE E O SACRIFÍCIO}

\author{
HEGEL, DEATH AND SACRIFICE
}

Georges Bataille
Apresentação
João Camillo Penna (UFRJ)

Alexandre Kojève, ou Kotjenikov, russo de nascimento, ministrou na Escola Prática de Altos Estudos, em Paris, entre 1933 e 1939, um célebre curso semanal, todas as segundas-feiras, sobre a Fenomenologia do espirito de Hegel. De família aristocrática, Kojève foi preso com seus pais em 1917, no calor da revolução. Na prisão, converteu-se ao bolchevismo. Emigrou em 1920 para a Alemanha, para Heildelberg, onde estudou filosofia clássica com Karl Jaspers. Com a ascensão do nazismo, mudou-se mais uma vez, dessa vez para a França, onde se instalou em 1928. Suas aulas foram responsáveis em larga medida pela introdução de Hegel a toda uma geração na França. O cerne de seu ensinamento consistia em uma longa e minuciosa explicação do capítulo IV, da segunda seção, da Fenomenologia do espírito, sobre a consciência de si e a dialética do senhor e do escravo. Dizia que nunca preparava suas aulas, apenas lia e comentava trechos da Fenomenologia que lhe interessavam.

Dentre os ouvintes assíduos do curso, notabilizam-se pensadores que se projetariam nas décadas seguintes, raros filósofos de profissão. Alguns nomes: Raymond Aron, Georges Bataille, Alexandre Koyré, Pierre Klossowski, Jacques Lacan, Maurice Merleau-Ponty, Raymond Queneau, Eric Weil, e esporadicamente, André Breton. Queneau, que coligiu as suas notas de curso e fixou o que conhecemos desse ensinamento essencialmente oral, em 1947, diz que Bataille aproveitou profundamente as liçóes do mestre, embora frequentemente dormitasse durante a aula.*

Kojève opera uma humanização do nada hegeliano: o ser humano traz o nada, o vazio, a morte para a natureza, onde ele não existia; ele é a "morte que vive uma vida humana".* Uma série de temas insistentes na cultura intelectual francesa, que virão a ser elaborados adiante, provém diretamente dessas aulas. Por exemplo, o tema do desaparecimento do homem e do fim da história,
* (QUENEAU, Raymond. "Premières confrontations avec Hegel". In: Critique. Hommage à Georges Bataille, août-septembre 1963: 699.)

* (KOJÈVE, Alexandre. Introdução à leitura de Hegel. Trad. Estela dos Santos Abreu. Rio de Janeiro: Contraponto/Eduerj, 2002: 513.) 
* (HEGEL, G. W. F. “Carta a Niethammer de 13 de outubro de 1806". In: Correspondance, I. Paris: Gallimard, coll. Tel, 1990: 115.$)$

* (KOJÈVE, Alexandre. Introdução à leitura de Hegel, loc.cit.: 411. Tradução modificada.)

* (DESCOMBES, Vincent. Le même et l'autre. Quarantecing ans de philosophie française (1933-1978. Paris: Minuit, 1979: 25.)

* (QUENEAU, Raymond, loc.cit.: 694.) retirado da passagem longamente meditada por Kojève da correspondência de Hegel, sobre a Batalha de Iena, cuja violência destruidora, Hegel, entấo morando em Iena, no momento de concluir a Fenomenologia, testemunhara. A realização histórica do espírito no mundo, encarnada na Revolução francesa, se completara com Napoleão, que Hegel vê em Iena. "Vi o Imperador - essa alma do mundo - deixar a cidade para fazer o reconhecimento das suas tropas; é efetivamente uma sensação maravilhosa ver um indivíduo semelhante que, concentrado assim em um ponto, montado em seu cavalo, estende-se sobre o mundo e o domina".* Para Kojève, Napoleão continha já em essência Stalin. Hegel havia visto, em suma, o acabamento da história. Na Batalha de Iena a vanguarda da humanidade atingira o seu termo. O que viria depois apenas universalizaria o programa de Napoleão-Robespierre. As duas guerras mundiais e as revoluçóes locais que se sucederiam consistiriam em um alinhamento do mundo às posição históricas europeias. O socialismo dito real não passa a seus olhos de uma "atualização sino-soviética do bonapartismo robespieriano"; os Estados Unidos de uma certa maneira teriam atingido "o estágio do 'comunismo' marxista".* Ou ainda o motivo do terror, retirado ele também diretamente do jacobinismo da revolução francesa, que aparecerá de maneira insistente na pena de Merleau-Ponty, Jean Paulhan etc. nos anos seguintes. Vincent Descombes conta que durante os acontecimentos de maio de 1968 - ano da morte de Kojève - ele teria dito: "o sangue não correu, nada portanto aconteceu".*

O confronto de Bataille com Hegel começa em 1929, nos primeiros artigos de Documents. Sua leitura muda com o tempo, e será preciso esperar a aulas de Kojève para ele fazer uma leitura criteriosa de Hegel. No início ele se diz anti-hegeliano. Bataille sustenta, acredita ele, contra Hegel, que o animal tem uma história como o ser humano, o que o leva a afirmar uma espécie de dialética (hegeliana) na própria natureza.*

É o panlogismo de Hegel que Bataille ataca nesse primeiro momento, ou seja, a redução abstrata da contradição ou antinomia entre eu e não eu, reduzida pela razão ao mesmo. Hegel seria responsável por fazer a "natureza entrar na ordem racional", escreve ele em "Figura humana". Nada poderia mais nos chocar, o mundo pacificado pela razão cessaria de nos surpreender. Para Hegel, o mundo material seria algo como a aparição de uma "mosca no nariz de um orador". O sistema hegeliano não teria dificuldades de reduzi-la a 
uma das "imperfeições da natureza". Contra Hegel, e invertendo-o, Bataille propóe "reduzir a aparição do eu à da mosca".*

A mesma mosca (uma outra) reaparece em "Hegel, a morte e o sacrifício": "estas moscas aqui são as mesmas do ano passado". Uma mosca morre, mas nada desapareceu; as moscas, como as ondas, são iguais a si mesmas. Um animal que come um outro animal náo modifica o mundo: "todo animal está no mundo como água dentro d'água".*

Haveria que seguir o fio insistente do motivo dos animais e especialmente dos insetos na obra batailliana. Maurice Heine, renovador dos estudos da obra de Sade na França, conhece Bataille na Biblioteca Nacional, onde este trabalhava, em 1939, e escreve em seu diário que Bataille lhe teria dito o seguinte na primeira vez que se viram: "Você está enganado em se colocar do ponto de vista da moral. Eu me coloco do ponto de vista do animal. Não sou um homem entre os homens. Sou um animal. As concessóes de forma que são exigidas de mim, estou pronto a concedê-las. Sou um mosquito, podem me esmagar, mas não farei um ruído inútil para assinalar a minha presença e não me comportarei como se fosse um elefante".*

A figura do saber absoluto, ponto final da sequência de figuras da Fenomenologia do espirito, o que Kojève traduzirá como a figura do sábio, consistiria no fechamento do círculo do conhecimento, em que saber e não saber, razão e loucura, potência e impotência, soberania e servidão, coincidiriam. Seria o "domingo da vida", conforme o título do romance de Queneau: nada mais a fazer senão para todo o sempre descansar, a humanidade afinal satisfeita se realizaria no ócio vazio, o trabalho convertido em arte, a atividade em monotonia, o ser humano tornado de novo animal. Para Bataille, trata-se antes de mais nada de "experimentar" Hegel, de transformar o programa hegeliano em experiência: "por contágio e imitação, realizo em mim o movimento circular de Hegel."* Realizar em si o círculo do saber consistiria em suma, nada mais nada menos, do que realizar no ipse, ou seja, em si, a totalidade universal, tornando-se... Deus, tomando ao mesmo tempo a filosofia em derrisão, e rindo da seriedade de Hegel e da filosofia. Realizar um Hegel, portanto, misturado de tintas nietzschianas. $\mathrm{O}$ mesmo Nietzsche que no momento de sossobrar na loucura resplandecia de lucidez, gritando nas ruas de Turim: "Eu sou Deus". Em A experiência inte-
* (BATAILLE, Georges. Oeuvres complètes, I. Paris: Gallimard, 1970: 184.)

* (BATAILLE, Georges. Théorie de la religion. Paris: Gallimard, coll. Idées, 1970: 25.)

* (Citado por SURYA, Michel. Georges Bataille, la mort à l'oeuvre. Paris: Gallimard, 1992: 232.)

* (BATAILLE, Georges. A experiência interior. Trad. Celso Libânio Coutinho, Magali Montagné e Antonio Ceschin. São Paulo: Ática, 1992: 117.)

* (NANCY, Jean-Luc. Une pensée finie. Paris: Galilée, 1990: 358.) 

imenso orgulho e obstinação de ir até o fim das coisas.

Ele teve sem dúvida o tom benzedor irritante, mas, em um retrato seu, idoso, imagino ler o esgotamento, o horror de estar no fundo das coisas - de ser Deus. Hegel, no momento em que o sistema se fechou, acreditou, durante dois anos, tornar-se louco: talvez tivesse medo de ter aceito o mal - que o sistema justifica e torna necessário; ou talvez ligando a certeza de ter atingido o saber absoluto ao acabamento da história - na passagem da existência ao estado de vazia monotonia - ele se viu, num sentido profundo, tornar-se morto; talvez mesmo essas tristezas diversas misturavam-se, nele, no horror mais profundo de ser Deus.*

Um pouco antes de sua morte, Bataille escreverá ainda a Kojève:

Trata-se de colocar na própria base (ou no fim) da reflexão hegeliana uma equivalência para com a loucura. Eu só saberia, a bem dizer, precisar do que se trata - ou melhor, do que se tratará - depois de havê-lo escrito. Mas essa espécie de termo [aboutissement] parece-me implicado no princípio - senáo do hegelianismo - pelo menos de seu objeto.*

* (SURYA, Michel. Georges Bataille, la mort à l'oeuvre, loc.cit.: 233.)
* (BATAILLE, Georges. Oeuvres complètes, V. Paris: Gallimard, 1973: 370.)

* (DERRIDA, Jacques. "De l'économie restreinte à l'économie générale. Un hegelianisme sans réserve". In: L'écriture et la différence. Paris: Seuil, coll. Points, 1967: 372.)

* (HEGEL, G. W. F. Phénomenologie de l'esprit, Préface, tome I, Trad. Jean Hyppolite. Paris: Aubier, Montaigne, 1939: 29.)

Em uma carta nunca enviada a Kojève, datada de 6 de dezembro de 1937, Bataille escreve o seguinte:

Mais frequentemente a negatividade impotente faz-se obra de arte: esta metamorfose, cujas consequências são reais, habitualmente respondem mal à situaçáo deixada pelo acabamento da história (ou para o pensamento do seu acabamento). Uma obra de arte responde eludindo, na medida em que a sua resposta se prolonga, ela náo responde a nenhuma situação particular, ela responde da pior maneira à situação do fim, quando eludir não é mais possível (quando chega a hora da verdade).*

Jacques Derrida afirma com razão que Bataille não vê diferença entre Hegel e Kojève, entre o Hegel de Kojève e a filosofia hegeliana tout court, ou entre a leitura de Kojève e a verdade profunda do marxismo.* Ele retira o grosso de sua tese sobre Hegel da célebre frase do Prefácio da Fenomenologia do espirito:

A morte [...] é o que há de mais terrível e sustentar a obra da morte é o que exige a maior força. A beleza impotente odeia o entendimento, porque ele exige dela aquilo de que ela náo é capaz. Ora, a vida do espírito não é a vida que se apavora diante da morte, e se preserva da destruição, mas a que suporta a morte e nela se conserva. [...] o Espírito só é essa potência na medida em que contempla o Negativo bem no rosto (e) se instala perto dele.* 
Blanchot, muito próximo de Bataille nesse sentido, cita o miolo da frase pelo menos cinco vezes no ensaio de 1948, "A literatura e o direito à morte".*

No fim da guerra Kojève abandona a filosofia, tornando-se, suprema ironia, um "filósofo dos domingos". Em 1945 ele vira tradutor no Ministério do Comércio Exterior, e rapidamente torna-se conselheiro da Direção das relações econômicas estrangeiras do Ministério da Fazenda. Foi, pelo que se diz, ainda, a eminência parda nas negociaçóes dos Acordos de Evian, que decretaram o cessar-fogo da Guerra da Argélia (1962). Surya aponta a coerência irônica entre o desenlace da vida de Kojève e seu ensinamento: com o fim da história acaba-se também a filosofia, e o filósofo deveria se engajar então nos serviços do estado.*

"Hegel, a morte e o sacrifício" parte quase que exclusivamente do apêndice de Introdução à leitura de Hegel, "A ideia da morte na filosofia de Hegel". Dali provém a quase totalidade de trechos que comenta. A Fenomenologia do espirito não passaria de uma "Autotanatografia do espírito", como o dirá Philippe Lacoue-Labarthe.* É aqui que Bataille desenha com nitidez a junçâo entre a temática etnográfica do sacrifício e a negatividade hegeliana (“[...] a que suporta a morte e nela se conserva [...]”), que desenvolverá em tantos outros textos.

O sacrifício é o cerne da leitura batailliana da arte, como experiência impossível da morte pela interposição da representação identificatória com o sacrifício da vítima. Mas como não se morre de fato, já que a morte é encenada, e vivida, "fazendo um só corpo com a arma do sacrifício" como simulacro, devemos rir disso e dela: tudo não passa de uma comédia!
* (BLANCHOT, Maurice. "A literatura e o direito à morte. In: A parte do fogo.Trad. Ana Maria Scherer. Rio de Janeiro: Rocco, 1997.)

* (SURYA, Michel, loc.cit.: 450.)

* (LACOUE-LABARTHE, Philippe. Agonie terminée, agonie interminable. Paris: Galilée, 2011: 74.) 
Hegel, a morte e o sacrifício ${ }^{1}$

Georges Bataille

Deucalion $^{2}$

O animal morre. Mas a morte do animal é o devir da consciência.

* (Citado por KOJÈVE, Alexandre. Introdução à leitura de Hegel. Trad. Estela dos Santos Abreu. Rio de Janeiro: Contraponto/Eduerj, 2002: 536.)

\section{A morte}

\section{A negatividade do homem}

Nas Conferências de 1805-1806, no momento da plena maturidade do seu pensamento, na época em que escrevia a Fenomenologia do espirito, Hegel exprimia assim o caráter negro da humanidade:

"O homem é essa noite, esse Nada [Néant] vazio, que contém tudo em sua simplicidade indivisa: uma variedade de um número infinito de representaçóes, de imagens, das quais nenhuma lhe vem à mente com clareza, ou [ainda], que não estão [ali] como realmente-presentes. É a noite, a interioridade - ou - intimidade da Natureza que existe aqui: - [o] Eu-pessoal puro. Em representaçóes fantasmagóricas, tudo ao redor está escuro: surge então uma cabeça ensanguentada aqui; mais adiante outra aparição branca; e elas desaparecem também de repente. É essa noite que se percebe quando se olha bem nos olhos de um homem: [mergulha-se o olhar] numa noite que torna-se terrível; é a noite do mundo que se apresenta [então] a nós". ${ }^{3 *}$

${ }^{1}$ Excerto de um estudo sobre o pensamento, fundamentalmente hegeliano, de Alexandre Kojève. Esse pensamento quer ser, na medida em que é possível, o pensamento de Hegel tal qual um espírito atual, sabendo o que Hegel não sabia (conhecendo, por exemplo, os acontecimentos após 1917, assim como a filosofia de Heidegger), poderia contê-lo e desenvolvê-lo. A originalidade e a coragem, é preciso dizê-lo, de Alexandre Kojève é ter percebido a impossibilidade de ir mais longe, a necessidade, consequentemente, de renunciar a fazer uma filosofia original, e daí, o recomeço interminável que é a confissão da vaidade do pensamento. 2 "Hegel, a morte e o sacrifício", Deucalion, n 5 (“Études hégéliennes"), n. 40 de Étre et penser, Cahiers de philosophie, Neuchâtel, outubro, 1955: 21-43.

No mesmo número, Deucalion publica "La critique des fondements de la dialectique hégélienne", redigido por Bataille em colaboração com Raymond Queneau para La critique sociale ( ${ }^{\circ} 5$, março, 1932).

${ }^{3}$ Trecho cotejado com o original de Kojève e com a traduçáo brasileira, ligeiramente modificada. Adotei ao longo de todo o texto o mesmo procedimento. (N. do T.) 
Bem entendido, esse "belo texto", em que se exprime o romantismo de Hegel, não deve ser entendido em sentido vago. Se Hegel foi romântico, foi talvez de uma maneira fundamental (ele foi de todo modo romântico para começar - em sua juventude -, quando era banalmente revolucionário), mas ele não viu então no romantismo o método pelo qual um espírito desdenhoso acreditava subordinar o mundo real ao arbitrário de seus sonhos. Alexandre Kojève, citando-as, diz dessas linhas que elas exprimem a "ideia central e última da filosofia hegeliana", a saber: "a ideia de que o fundamento e a fonte da realidade objetiva [Wirklichkeit] e da existência empírica [Dasein] humanas são o Nada que se manifesta enquanto Ação negativa ou criativa, livre e consciente de si mesma”.

Para dar acesso ao mundo desconcertante de Hegel, acreditei dever marcar nele, por uma visão sensível, ao mesmo tempo os contrastes violentos e a unidade última.

Para Kojève, “a filosofia 'dialética' ou antropológica de Hegel é, em última análise, uma filosofia da morte (ou o que dá no mesmo: do ateísmo)"**

Mas se o homem é "a morte que vive uma vida humana", ${ }^{*}$ essa negatividade do homem, dada na morte pelo fato de que essencialmente a morte do homem é voluntária (derivando de riscos assumidos sem necessidade, sem razóes biológicas), não é menos o princípio da ação. Para Hegel, com efeito, a Ação é Negatividade, e a Negatividade, Ação. De um lado, o homem que nega a Natureza ao introduzir nela, como um reverso, a anomalia de um "Eu pessoal puro" - está presente no seio dessa Natureza como uma noite na luz, como uma intimidade na exterioridade dessas coisas que são em si - como uma fantasmagoria em que nada se compóe senão para se desfazer, nada aparece senão para desaparecer, nada que não seja, sem trégua, absorvido no aniquilamento [néantissement] do tempo e que daí não tire a beleza do sonho. Mas eis o aspecto complementar: essa negação da Natureza não é apenas dada na consciência, onde aparece (mas para desaparecer) o que é em si- essa negaçáo se exterioriza e, exteriorizando-se, muda realmente (em si) a realidade da Natureza. O homem trabalha e combate: transforma o dado ou a natureza: cria, ao destruí-la, o mundo, um mundo que não existia. Há, de um lado, poesia: a destruição, surgida e se diluindo, de uma cabeça ensanguentada; de outro, Ação: o trabalho, a luta. De um lado, o "Nada [Néant] puro", em que o homem "não difere do Nada a não ser por um certo tempo".* Do outro, um Mundo his-

* (Op. cit.: 536. Ênfase de Bataille.)

* (Op. cit.: 504.)

* (Op. cit.: 513.) 
tórico, em que a Negatividade do homem, esse Nada que o corrói por dentro, cria o conjunto do real concreto (ao mesmo tempo objeto e sujeito, mundo real mudado ou não, homem que pensa e muda o mundo).

\section{A filosofia de Hegel é uma filosofia da morte- ou do ateísmo ${ }^{4}$}

É o caráter essencial - e novo - da filosofia hegeliana descrever a totalidade do que é. E consequentemente, ao mesmo tempo em que dá conta de tudo o que aparece aos nossos olhos, dá conta solidariamente do pensamento e da linguagem que exprimem revelam - essa aparição.

"A meu ver", diz Hegel, "tudo depende de exprimirmos e compreendermos a Verdade não (apenas) como substância, mas também como sujeito." (Phénomenologie de l'esprit, Préface, Traduction de Jean Hyppolite, t.I: 17, 1. 1-4. [GB].)

Em outras palavras, o conhecimento da Natureza é incompleto, ele só considera e só pode considerar, entidades abstratas, isoladas de um todo, de uma totalidade indissolúvel, que é só ela concreta. O conhecimento deve ser ao mesmo tempo antropológico: "além das bases ontológicas da realidade natural", escreve Kojève, "ela deve buscar as da realidade humana, que é a única capaz de se revelar a si própria pelo Discurso".* Bem entendido, essa antropologia não considera o Homem à maneira das ciências modernas, mas como um movimento que é impossível isolar no seio da totalidade. Em um certo sentido, é antes uma teologia, onde o homem teria tomado o lugar de Deus.

\footnotetext{
${ }^{4}$ Neste parágrafo, e no parágrafo seguinte, retomo sob uma outra forma o que diz Alexandre Kojève. Mas náo somente sob uma outra forma; devo essencialmente desenvolver a segunda parte dessa frase, difícil, à primeira vista, de ser compreendida em seu caráter concreto: "O ser ou o aniquilamento [néantissement] do 'Sujeito' é o aniquilamento [anéantissement] temporalizante do Ser, que deve ser antes de ser aniquilado: o ser do 'Sujeito' tem necessariamente um começo. E sendo aniquilamento [néantissement] (temporal) do nada [néant] no Ser, sendo nada que aniquila [néantit] (enquanto Tempo), o 'Sujeito' é essencialmente negação de si mesmo: ele tem necessariamente um fim.” Em particular, segui para isso (como já o fiz no parágrafo precedente) a parte da Introdução à leitura de Hegel que responde às partes 2 e 3 do presente estudo, a saber: Apêndice II, "A ideia da morte na filosofia de Hegel": 495-536.

${ }^{5}$ Preferi não utilizar a tradução brasileira da Fenomenologia do espirito, por ela se distanciar muito da tradução utilizada por Bataille, de Jean Hyppolite, que permaneceu por muito tempo a tradução canônica de Hegel na França. (N. do T.)
} 
Mas para Hegel, a realidade humana que ele descreve, no seio e no centro da totalidade, é muito diferente da realidade da filosofia grega. Sua antropologia é a da tradição judaico-cristã, que sublinha no Homem a liberdade, a historicidade e a individualidade. Assim como o homem judaico-cristão, o homem hegeliano é um ser espiritual (isto é, "dialético"). Contudo, para o mundo judaico-cristão, a "espiritualidade" só se realiza e só se manifesta plenamente no além, e o Espírito propriamente dito, o Espírito verdadeiramente "objetivamente real", é Deus: "um ser infinito e eterno". Segundo Hegel, o ser "espiritual" ou "dialético" é necessariamente temporale finito". Isso quer dizer que apenas a morte assegura a existência de um ser espiritual ou "dialético" no sentido hegeliano. Se o animal que constitui o ser natural do homem náo morresse, ou melhor, se náo tivesse a morte em si como a fonte de sua angústia, tanto mais forte na medida em que ele a busca, a deseja, e às vezes busca voluntariamente a morte, não haveria nem homem, nem liberdade, nem história, nem indivíduo. Em outras palavras, se ele se compraz naquilo que no entanto lhe dá medo, se ele é o ser, idêntico a si mesmo, que póe o próprio ser (idêntico) em jogo, o homem é então um Homem em verdade: ele se separa do animal. Ele não é mais, doravante, como uma pedra, um dado imutável, ele porta em si a Negatividade; e a força, a violência da negatividade, o jogam no movimento incessante da história, que o muda, e que sozinha realiza através do tempo a totalidade do real concreto. Só a história tem o poder de acabar [achever $]^{6}$ o que é, de acabá-lo no desenrolar do tempo. Assim, a ideia de um Deus eterno e imutável não passa, nessa perspectiva, de um acabamento [achèvement] provisório que sobrevive enquanto espera algo melhor. Apenas a história realizada/ acabada e o espírito do Sábio (de Hegel), no qual a história revelou, depois acabou [acheva] de revelar, o pleno desenvolvimento do ser e da totalidade de seu devir, ocupam uma situação soberana, que Deus ocupa apenas provisoriamente, como regente.

\footnotetext{
6 "Achever", "achèvement", traduz o verbo "vollenden" e derivados em alemão. Em português, deve ser traduzido por "acabar" no sentido de "realizar". Optei por traduzi-lo em geral por "acabar". Observe-se, no entanto, que "acabar" contém em português uma equivocidade (destruir e completar), aliás perfeitamente dialética, uma equivocidade bem ao gosto de Hegel, que não existe nem em alemão, nem em francês. (N. do T.)
} 
Essa maneira de ver pode com razão ser tida por cômica. Hegel, aliás, não falou disso explicitamente. Os textos em que ela se afirmou implicitamente são ambíguos, e a sua extrema dificuldade acabou por lhes furtar a luz. O próprio Kojève observa prudência. Ele fala deles sem gravidade, evitando precisar-lhe as consequências. Para exprimir como convém a situação em que Hegel se enfiou, sem dúvida involuntariamente, seria preciso o tom, ou pelo menos, sob uma forma contida, o horror da tragédia. Mas as coisas teriam logo um andamento cômico.

De qualquer maneira, passar pela morte faz de tal modo falta à figura divina que um mito situado na tradição associou a morte, e a angústia da morte, ao Deus eterno e único, da esfera judaicocristâ. A morte de Jesus participa da comédia na medida em que não saberíamos sem arbitrário introduzir o esquecimento da sua divindade eterna - que lhe pertence - na consciência de um Deus todo-poderoso e infinito. $\mathrm{O}$ mito cristão, exatamente, antecipou o "saber absoluto" de Hegel, fundando sobre o fato de que nada de divino (no sentido pré-cristão de sagrado) é possível que não seja finito. Mas a consciência vaga em que o mito (cristáo) da morte de Deus se formou, apesar de tudo, diferia da de Hegel: para adulterar no sentido da totalidade uma figura de Deus que limitava o infinito, foi possível introduzir, em contradição de um fundamento, um movimento em direção ao finito.

Hegel pôde - precisou - compor a soma (a Totalidade) dos movimentos que se produziram na história. Mas o humor, parece, é incompatível com o trabalho, e com a aplicação exigida pelas coisas. Voltarei a esse assunto, tudo o que fiz, por enquanto, foi embaralhar as cartas... É difícil passar de uma humanidade que a grandeza divina humilhou àquela... do Sábio divinizado, soberano e que infla a sua grandeza a partir da vaidade humana.

\section{Um texto capital}

No que precede, uma única exigência se depreende de modo preciso: não pode haver autenticamente Sabedoria (Saber absoluto, nem geralmente nada que se aproxime) se o Sábio não se eleva, se ouso dizer, à altura da morte, qualquer que seja a angústia que ele sofra com isso.

* (Trad. Hyppolite, t.1: 29 Citada por Kojève, op. cit.: 505-506.)

Uma passagem do Prefácio da Fenomenologia do espirito* exprime com força a necessidade de uma tal atitude. Nenhuma 
dúvida de que esse texto admirável, de antemão, tenha "uma importância capital", não somente para a inteligência de Hegel, mas em todos os sentidos.

"A morte", escreve Hegel "- se quisermos chamar assim essa irrealidade - é o que há de mais terrível e sustentar a obra da morte é o que exige a maior força. A beleza impotente odeia o entendimento, porque ele exige dela aquilo de que ela não é capaz. Ora, a vida do espírito não é a vida que se apavora diante da morte, e se preserva da destruição, mas a que suporta a morte e nela se conserva. O espírito só obtém sua verdade ao encontrar a si mesmo no dilaceramento absoluto. Ele não é essa potência (prodigiosa) sendo o Positivo que se desvia do Negativo, como quando dizemos de algo: isso não é nada ou (isso é) falso, e, tendo-o (assim) liquidado, passamos dali a outra coisa; não, o Espírito só é essa potência na medida em que contempla o Negativo bem no rosto (e) se instala perto dele. Essa estadia-prolongada é a força mágica que transpóe o negativo no Ser-dado."

\section{A negação humana da natureza e do ser natural do homem}

Em princípio, eu deveria ter começado mais acima a passagem citada. Quis não pesar esse texto com as linhas "enigmáticas" que as precedem. Mas indicarei o sentido de algumas linhas omitidas retomando a interpretação de Kojève, sem a qual a sequência, a despeito de uma aparência relativamente clara, poderia nos permanecer inacessível.

Para Hegel, é ao mesmo tempo fundamental e inteiramente digno de espanto que o entendimento do homem (quer dizer, a linguagem, o discurso) tenha tido a força (trata-se de uma potência incomparável) de separar da Totalidade os seus elementos constitutivos. Estes elementos (esta árvore, este pássaro, esta pedra) são de fato inseparáveis do todo. Eles estâo "ligados entre si por ligaçóes espaciais e temporais, e até materiais, que são indissolúveis." A separação deles implica a Negatividade humana a respeito da Natureza, de que falei sem destacar uma consequência decisiva. Esse homem negando a natureza, de fato, náo poderia de maneira nenhuma existir fora dela. Ele não é apenas um homem negando a Natureza, ele é, em primeiro lugar, um animal, isto é, a coisa mesma que ele nega: ele não pode portanto negar a Natureza sem se negar a si próprio. O caráter de totalidade do homem é dado na expressão bizarra de Kojève: essa totalidade é em primeiro lugar Natureza (ser natural), é 
“o animal antropológico" (A Natureza, o animal indissoluvelmente ligado ao conjunto da Natureza, e que suporta o Homem). Assim, a Negatividade humana, o desejo eficaz que tem o Homem de negar a Natureza destruindo-a - reduzindo-a a seus próprios fins: ele faz dela por exemplo uma ferramenta e a ferramenta será o modelo do objeto isolado da Natureza - não pode parar diante de si mesmo: enquanto é Natureza, o Homem se expóe à sua própria Negatividade. Negar a Natureza é negar o animal que serve de suporte à Negatividade do Homem. Sem dúvida não é o entendimento que quebra a unidade da Natureza que quer que haja morte de homem, mas a Ação separadora do entendimento implica a energia monstruosa do pensamento, do "puro Eu abstrato", que se opóe essencialmente à fusão, ao caráter inseparável dos elementos - constitutivos do conjunto - que, com firmeza, mantém a separação entre eles.

É a posição como tal do ser separado do homem, é o seu isolamento na Natureza, e, consequentemente, o seu isolamento no meio de seus semelhantes, que o condenam a desaparecer de uma maneira definitiva. $\mathrm{O}$ animal, não negando nada, perdido, sem oferecer oposição, em meio à animalidade global, assim como a própria animalidade está perdida na Natureza (e na totalidade do que é), não desaparece verdadeiramente... Sem dúvida, a mosca individual morre, mas estas moscas aqui são as mesmas do ano passado. As do ano passado estariam mortas?... É possível, mas nada desapareceu. As moscas permanecem, iguais a elas mesmas, como o são as ondas do mar. Aparentemente é forçoso ser assim: um biólogo separa esta mosca aqui do turbilhão, um traço de pincel basta. Mas ele a separa para si mesmo, ele não a separa para as moscas. Para se separar dos outros, a "mosca" precisaria da força monstruosa do entendimento: entáo ela se nomearia, fazendo o que em geral a linguagem opera pelo entendimento, que só ele funda a separação dos elementos, e ao fundá-la se funda sobre ela, no interior de um mundo formado de entidades separadas e nomeadas. Mas nesse jogo o animal humano encontra a morte: ele encontra precisamente a morte humana, a única que amedronta, que horripila, mas amedronta e horripila apenas o homem absorvido na consciência do seu desaparecimento futuro, enquanto ser separado e insubstituível; a única verdadeira morte, que supóe a separação e, pelo discurso que separa, a consciência de ser separado. 
Até aqui o texto de Hegel apresenta uma verdade simples e comum, - mas enunciada de uma maneira filosófica e, mais do que isso, propriamente sibilina. Na passagem citada do Prefácio, Hegel ao contrário afirma, e descreve, um momento pessoal de violência. Hegel, ou seja, o Sábio, a quem um Saber absoluto confere a satisfação definitiva. Não é uma violência enfurecida. O que Hegel desencadeia não é a violência da Natureza, é a energia ou a violência do Entendimento, a Negatividade do Entendimento, opondo-se à beleza pura do sonho, que não pode agir, que é impotente.

De fato, a beleza do sonho remete ao mundo onde nada está ainda separado do que está em volta, onde cada elemento, ao contrário dos objetos abstratos do Entendimento, é dado concretamente, no espaço e no tempo. Mas a beleza não pode agir. Pode ser e se conservar. Agindo, ela não seria mais, pois a Ação destruiria antes o que ela é: a beleza, que não busca nada, que é, que se recusa a se perturbar, mas que a força do Entendimento perturba. A beleza não tem, aliás, o poder de responder à requisição do Entendimento, que lhe pede para sustentar, mantendo-a, a obra da morte humana. Ela é incapaz disso, no sentido de que ao sustentar essa obra, ela estaria engajada na Ação. A beleza é soberana, ela é um fim, ou ela não é: é por isso que ela não é suscetível de agir, ela é em, seu princípio mesmo, impotente e não pode ceder à negação ativa do Entendimento que muda o mundo e torna-se ele próprio uma coisa diferente do que é. ${ }^{7}$

Essa beleza sem consciência de si mesma não pode portanto realmente, mas não pela mesma razão que a vida que "recua de hor-

\footnotetext{
${ }^{7}$ Aqui a minha interpretação difere um pouco da de Kojève (op.cit.: 512). Kojève diz simplesmente que a "beleza impotente é incapaz de dobrar-se às exigências do Entendimento. O esteta, o romântico, o místico fogem da ideia da morte e falam do próprio Nada como de algo que existe." (Ênfase de Bataille. [N. T.]) Em particular, ele define assim o místico admiravelmente. Mas a mesma ambiguidade se encontra no filósofo (em Hegel, em Heidegger), ao menos ao final. Na verdade, Kojève me parece estar enganado ao não considerar, para além do misticismo clássico, um "misticismo consciente", que tem consciência de fazer um Ser do Nada, ao definir, além de tudo, esse impasse como o de uma Negatividade que náo teria mais campo de Açáo (no fim da história). O místico ateu, consciente de si, consciente de dever morrer e de desaparecer, viveria, como Hegel o diz evidentemente de si mesmo, "no dilaceramento absoluto"; mas, para ele, não se trata de um período: em oposição a Hegel, ele não encontraria uma saída, "contemplando o Negativo bem no rosto", mas não podendo jamais transpô-lo em Ser, recusando-se a fazê-lo e mantendo-se na ambiguidade.
} 
ror diante da morte e quer se preservar do aniquilamento", suportar a morte e se conservar nela. Essa beleza que não age sofre pelo menos quando sente que se parte em pedaços a Totalidade do que é (do real-concreto), que é profundamente indissolúvel. Ela gostaria ela própria de permanecer o signo de um acordo do real consigo mesmo. Ela não pode tornar-se essa Negatividade consciente, desperta nesse dilaceramento, esse olhar lúcido, absorvido no Negativo. Esta última atitude supóe, antes dela, a luta violenta ou laboriosa do Homem contra a Natureza, de que ela é a conclusão. É a luta histórica em que o Homem se constituiu como "Sujeito" ou como "Eu abstrato" do "Entendimento", como ser separado e nomeado.

"Quer dizer", precisa Kojève, "que o pensamento e o discurso, revelador do real, nascem da Ação negadora que realiza o Nada aniquilando [anéantissant] o Ser: o ser dado do Homem (na Luta) e o ser dado da Natureza (pelo Trabalho - que resulta aliás do contato real com a morte na Luta). Quer dizer entáo que o próprio ser humano não é nada além dessa Ação: ele é a morte que vive uma vida humana."*

Insisto sobre a conexão contínua de um aspecto abissal e de um aspecto coriáceo, terra a terra, dessa filosofia, a única que teve a pretensão de ser completa. As possibilidades divergentes das figuras humanas opostas ali se afrontam e se conjugam, a figura do moribundo e a do homem orgulhoso que se desvia da morte, a figura do senhor e a do homem pregado ao trabalho, a figura do revolucionário e a do cético, cujo interesse egoísta limita o desejo. Essa filosofia não é apenas uma filosofia da morte. É também uma filosofia da luta de classes e do trabalho.

Mas, nos limites deste estudo, não tenho a intenção de enfrentar a outra vertente, gostaria de aproximar essa doutrina hegeliana da morte daquilo que sabemos do "sacrifício".

\section{O sacrifício}

O sacrifício, de um lado, e, de outro, o olhar de Hegel absorvido pela morte e pelo sacrifício

Não falarei da interpretação do sacrifício dada por Hegel no capítulo da Fenomenologia consagrado à Religião. ${ }^{8}$ Ela tem sem

${ }^{8}$ Fenomenologia, capítulo VIII: A Religião, B: A Religião estética, a) A obra de arte abstrata (tomo II: 235-236). Nessas duas páginas, Hegel mostra o desapa- 
dúvida um sentido no desenvolvimento do capítulo, mas distancia do essencial, e tem, a meu ver, do ponto de vista da teoria do sacrifício, um interesse menor do que a representaçáo implícita no texto do Prefácio que continuo a comentar.

Do sacrifício, posso dizer essencialmente, no plano da filosofia de Hegel, que, em um certo sentido, o Homem revelou e fundou a verdade humana sacrificando: no sacrifício, ele destruiu o animal ${ }^{9}$ nele mesmo, deixando subsistir, de si mesmo e do animal, apenas a verdade não corporal descrita por Hegel, que, do homem, faz segundo a expressão de Heidegger - um ser para a morte (Sein zum Tode), ou - segundo a expressão do próprio Kojève - "a morte que vive uma vida humana”.

$\mathrm{Na}$ verdade, o problema de Hegel é dado na ação do sacrifício. No sacrifício, a morte, de um lado, atinge essencialmente o ser corporal; e é, por outro lado, no sacrifício que exatamente "a morte vive uma vida humana". Seria até mesmo preciso dizer que o sacrifício é precisamente a resposta à exigência de Hegel, de quem retomarei a fórmula:

"O espírito só obtém a sua verdade ao encontrar a si mesmo no dilaceramento absoluto. Ele não é essa potência (prodigiosa) sendo o Positivo que se afasta do Negativo [...] não, o Espírito só é essa potência na medida em que contempla o Negativo bem no rosto (e) se instala perto dele [...]."

Se levarmos em conta o fato de que a instituição do sacrifício é praticamente universal, é claro que a Negatividade, encarnada na morte do homem, não somente não é uma construção arbitrária de Hegel, mas desempenhou um papel no espírito dos homens mais simples, sem acordes análogos àqueles que as cerimônias de uma Igreja regulam desde sempre - no entanto de uma maneira unívoca. É impressionante ver que uma Negatividade comum manteve através da terra um paralelismo estreito com o desenvolvimento de instituições bastante estáveis, tendo a mesma forma e os mesmos efeitos.

recimento da essência objetiva, mas sem desenvolver-lhe o alcance. Na segunda página, Hegel se limita a consideraçooes próprias à "religião estética" (a religiáo dos Gregos).

${ }^{9}$ Contudo, embora o sacrifício do animal pareça anterior ao do homem, nada prova que a escolha do animal significa o desejo inconsciente de se opor ao animal enquanto tal, é somente ao ser corporal, ao ser dado, que o homem se opóe. Ele se opóe, aliás, também à planta. 
Que ele viva ou morra, o homem não pode conhecer imediatamente a morte

Falarei mais adiante de diferenças profundas entre o homem do sacrifício, que opera na ignorância (na inconsciência) das causas e consequências do que faz, e o Sábio (Hegel), que se rende às implicações de um Saber absoluto a seus próprios olhos.

Apesar dessas diferenças, trata-se sempre de manifestar o Negativo (e sempre, sob uma forma concreta, isto é, no seio da Totalidade, cujos elementos constitutivos são inseparáveis). A manifestação privilegiada da Negatividade é a morte, mas a morte na verdade não revela nada. É em princípio o seu ser natural, animal, cuja morte revela o Homem a si mesmo, mas a revelação nunca tem lugar. Pois uma vez morto o ser animal que o suporta, o próprio ser humano deixou de ser. Para que o homem ao final se revele a si mesmo, ele deveria morrer, mas seria preciso fazê-lo em vida - olhando-se deixar de ser. Em outras palavras, a própria morte deveria tornar-se consciência (de si), no momento mesmo em que aniquila o ser consciente. É em um certo sentido o que tem lugar (que está pelo menos à beira de ter lugar, ou que tem lugar de uma maneira fugidia, inapreensível), por meio de um subterfúgio. No sacrifício, o sacrificante se identifica com o animal atingido pela morte. Assim, ele morre vendo-se morrer, e até mesmo de certo modo, por sua própria vontade, fazendo um só corpo com a arma do sacrifício. Mas é uma comédia!

Seria em todo o caso uma comédia se existisse algum outro método que revelasse ao vivente a invasão da morte: esse acabamento do ser finito, que só a sua Negatividade e apenas ela pode realizar, que o mata, o termina [finit] e definitivamente o suprime. Para Hegel, a satisfação não pode ter lugar, o desejo só pode ser apaziguado na consciência da morte. A satisfação seria de fato contrária ao que a morte designa, se ela supusesse a exceção da morte, se o ser satisfeito, não tendo consciência, e plenamente, do que é de uma maneira constitutiva, isto é, mortal, se ele tivesse mais tarde que ser expulso da satisfação pela morte. É por isso que a consciência que ele tem de si deve refletir (e dele ser um reflexo ${ }^{10}$ ) esse

\footnotetext{
${ }^{10}$ Bataille utiliza aqui dois verbos, "réfléchir" e "refléter", "refletir" e "produzir um reflexo" físico, que são normalmente traduzidos em português por "refletir". Uso "e ser um reflexo" ("refléter") para dar uma ideia do duplo sentido. (N. do T.)
} 
movimento de negatividade que o cria, que justamente faz dele um homem pela razão de que um dia o matará.

A sua própria negatividade o matará, mas para ele, doravante, nada mais será: a sua morte é criativa, mas se a consciência da morte - da maravilhosa magia da morte - não o toca antes de ele morrer, será para ele, enquanto viver, como se a morte não o devesse atingir, e essa morte por vir não poderá lhe dar um caráter humano. Assim, seria preciso, a qualquer preço, que o homem vivesse no momento em que ele morre realmente, ou que ele vivesse com a impressão de morrer realmente.

\section{O conhecimento da morte não pode deixar} de se valer de um subterfúgio: o espetáculo

Essa dificuldade anuncia a necessidade do espetáculo, ou geralmente, da representação, sem cuja repetiçáa ${ }^{11}$ poderíamos, diante da morte, permanecer estrangeiros, ignorantes, como aparentemente o são os animais. Nada é menos animal, de fato, do que a ficção, mais ou menos distanciada do real, da morte.

O Homem não vive somente de pão, mas de comédias com as quais se engana voluntariamente. No Homem, é o animal, é o ser natural, que come. Mas o Homem assiste ao culto e ao espetáculo. Ou ainda, ele pode ler: portanto a literatura prolonga nele, na medida em que é soberana, autêntica, a magia obsedante dos espetáculos, trágicos ou cômicos.

Trata-se, pelo menos na tragédia, ${ }^{12}$ de identificar-nos com algum personagem que morre, e de acreditar morrer embora estejamos vivos. Além disso, a imaginação pura e simples é suficiente, mas ela tem o mesmo sentido que os subterfúgios clássicos, os espetáculos ou os livros, aos quais a multidão recorre.

Acordo e desacordo das condutas ingênuas e sobre a reação lúcida de Hegel

Ao aproximá-la do sacrifício e a partir daí do tema primeiro da representação (da arte, das festas, dos espetáculos), eu quis mostrar que a reação de Hegel é a conduta humana fundamental. Não é uma fantasia, uma conduta estranha, é por excelência a expressão que a

11 "Répétition" tem em francês o duplo sentido de "repetição" e de "ensaio" no sentido teatral do termo. (N. do T.)

${ }^{12}$ Falo mais adiante da comédia. 
tradição repetia ao infinito. Não é Hegel isoladamente, é a humanidade inteira que, em toda parte e sempre, quis, por um desvio, discernir o que a morte ao mesmo tempo lhe dava e lhe roubava.

Entre Hegel e o homem do sacrifício subsiste no entanto uma diferença profunda. Hegel despertou de uma maneira consciente para a representação que ele se deu do Negativo: ele o situava, lucidamente, em um ponto definido do "discurso coerente" pelo qual se revelava para ele próprio Essa Totalidade incluindo o discurso que a revela. Enquanto que o homem do sacrifício, a quem faltou um conhecimento discursivo do que fazia, só tinha o conhecimento "sensível", isto é, obscuro, reduzido à emoção ininteligível. É verdade que o próprio Hegel, além do discurso, e a despeito de si mesmo (em um "dilaceramento absoluto"), recebeu ainda mais violentamente o choque da morte. Mais violentamente sobretudo pela razáo de que o amplo movimento do discurso estendia sua envergadura ilimitadamente, isto é, no âmbito da Totalidade do real. Para Hegel, sem nenhuma dúvida, o fato de permanecer vivo era simplesmente um agravante. Enquanto que o homem do sacrifício mantém a sua vida essencialmente. Ele a mantém não somente no sentido de que a vida é necessária à representação da morte, mas ele pretendia enriquecê-la. Mas tomando a coisa pelo alto, a comoção [émoi] sensível e querida no sacrifício tinha mais interesse que a sensibilidade involuntária de Hegel. A comoção [émoi] de que falo é conhecida, é definível, e é o horror sagrado: a experiência ao mesmo tempo mais angustiante e mais rica possível, que não se limita por si mesma ao dilaceramento, que se abre, ao contrário, assim como uma cortina de teatro, para um além deste mundo, em que o dia que nasce transfigura todas as coisas e destrói o seu sentido limitado.

Com efeito, se a atitude de Hegel opóe à ingenuidade do sacrifício a consciência sábia, e a ordenação sem fim de um pensamento discursivo, essa consciência, essa ordenaçáa, têm ainda um ponto obscuro: não se poderia dizer que Hegel desconhecesse o "momento" do sacrifício: esse "momento" está incluído, implicado, em todo o movimento da Fenomenologia - onde é a Negatividade da morte, na medida em que o homem a assume, que faz um homem do animal humano. Mas não tendo visto que o sacrifício por si só dava testemunho de todo o movimento da morte, ${ }^{13}$

${ }^{13}$ Talvez por falta de uma experiência religiosa católica. Imagino o catolicismo mais próximo da experiência pagã. Quero dizer, de uma experiência religiosa uni- 
a experiência final - e própria ao Sábio - descrita no Prefácio da Fenomenologia foi antes de mais nada inicial e universal- ele não soube a que ponto tinha razão - com que exatidão descreveu o movimento íntimo da Negatividade - ele não separou claramente a morte do sentimento de tristeza a que a experiência ingênua opóe uma espécie de plataforma giratória de emoçóes.

\section{A tristeza da morte e o prazer}

O caráter unívoco da morte para Hegel inspira justamente a Kojève o comentário seguinte, que se aplica ainda à mesma passagem do Prefácio:* "Sem dúvida, a ideia da morte não aumenta o bem-estar do Homem; não o torna feliz e não lhe proporciona nenhum prazer." Kojève perguntou-se de que maneira a satisfação resulta de uma estadia junto ao Negativo, de um face a face com a morte, ele acreditou dever, honestamente, rejeitar a satisfação vulgar. $\mathrm{O}$ fato de o próprio Hegel dizer do Espírito, a esse respeito, que ele "só obtém a sua verdade quando se encontra no dilaceramento absoluto" vai de par, em princípio, com a Negação de Kojève. Consequentemente, seria até mesmo supérfluo insistir... Kojève diz simplesmente que a ideia da morte "é a única que pode satisfazer [o] orgulho [do homem]"... De fato, o desejo de ser "reconhecido", que Hegel coloca na origem das lutas históricas, poderia se exprimir em uma atitude intrépida, própria a fazer valer um caráter. "Só ao ser ou ao se sentir como mortal ou finito, diz Kojève, isto é, ao existir e ao se sentir existir num universo sem além ou sem Deus, é que o Homem pode afirmar e fazer reconhecer sua liberdade, sua historicidade e sua individualidade "únicas no mundo". * Mas se Kojève

* (KOJÈVE, op. cit.: 514. As palavras são sublinhadas pelo autor.)

* (KOJÈVE, op. cit.: 514.)

versal de que a Reforma se distancia. Talvez apenas uma piedade católica profunda pudesse haver introduzido o sentimento íntimo sem o qual a fenomenologia do sacrifício seria impossível. Os conhecimentos modernos, bem mais extensos que os do tempo de Hegel, contribuíram seguramente para a solução desse enigma fundamental (por que, sem razáo plausível, a humanidade em geral "sacrificou"?), mas creio seriamente que uma descrição fenomenológica correta teria inevitavelmente que apoiar-se no mínimo sobre um periodo católico.

- Mas de qualquer maneira, Hegel, hostil ao ser sem fazer, - ao que é simplesmente, e não é $A c ̧ a ̃ o,-$ interessava-se mais pela morte militar; foi através dela que ele percebeu o tema do sacrifício (mas ele emprega a própria palavra em um sentido moral): "A condição-de-soldado", diz ele, nas Conferências de 1805-1806, "e a guerra são o sacrifício objetivamente real do Eu-pessoal, o perigo de morte para o particular, - essa contemplação de sua Negatividade abstrata imediata..." (CEuvres, XX: 261-262, citada por Kojève: 522.) O sacrifício religioso não deixa de ter, do próprio ponto de vista de Hegel, uma significação essencial. 
afasta a satisfação vulgar, a felicidade, ele afasta agora o "dilaceramento absoluto" de que fala Hegel: de fato, um tal dilaceramento se concilia mal com o desejo de ser reconhecido.

A satisfação e o dilaceramento coincidem entretanto em um ponto, eles se conciliam com o prazer. Essa coincidência tem lugar no "sacrifício"; quer dizer, geralmente, na forma ingênua da vida, em toda existência no tempo presente, que manifeste o que o Homem é: o que ele significa de novo no mundo após haver se tornado o Homem, e com a condição de ter satisfeito as suas necessidades "animais".

De todo o modo, o prazer, a menos o prazer dos sentidos, é tal que, a seu respeito, a afirmação de Kojève dificilmente poderia ser mantida: a ideia da morte contribui, de uma certa maneira e em certos casos, para multiplicar o prazer dos sentidos. Creio mesmo que, sob a forma de sujeira, o mundo (ou melhor, a imagística geral) da morte está na base do erotismo. O sentimento do pecado se liga na consciência clara à ideia da morte, e do mesmo modo o sentimento do pecado se liga ao prazer. ${ }^{14}$ Não há, de fato, prazer humano sem uma situação irregular, sem a ruptura de uma proibição, da qual, atualmente, a mais simples - e ao mesmo tempo, a mais forte - é a da nudez.

Mais do que isso, a posse foi associada, em seu tempo, à imagem do sacrifício: era um sacrifício de que a mulher era a vítima... Essa associação da poesia antiga é cheia de sentido: ela remete a um estado preciso da sensibilidade em que o elemento sacrificial, o sentimento de horror sagrado se ligou até mesmo, em estado atenuado, ao prazer edulcorado; em que, por outro lado, o gosto do sacrifício e a emoção que ele liberava nada tinham que parecesse contrário ao gozo.

É preciso dizer também que o sacrifício era, como a tragédia, o elemento de uma festa: ele anunciava uma alegria deletéria, cega, e todo o perigo dessa alegria, mas este é justamente o princípio da alegria humana: ela excede e ameaça de morte aqueles que carrega em seu movimento.

A angústia alegre, a alegria angustiada

À associaçấo da morte ao prazer, que náo é dada, pelo menos não é imediatamente dada na consciência, opóe-se evidentemente a

${ }^{14}$ Isso é pelo menos possível, e, em se tratando das proibições mais comuns, é banal. 
tristeza da morte, sempre como pano de fundo da consciência. Em princípio, conscientemente, a humanidade "recua de horror diante da morte". Em seu princípio, os efeitos destruidores da Negatividade têm a Natureza por objeto. Mas se a Negatividade do Homem o leva colocar-se diante do perigo, se ele faz de si mesmo, pelo menos do animal, do ser natural que ele é, o objeto de sua negação destruidora, sua condição banal é a inconsciência em que se encontra em relaçáo à causa e aos efeitos de seus movimentos. Ora, foi essencial para Hegel tomar consciência da Negatividade como tal, capturar-lhe o horror, nesse caso o horror da morte, sustentando e olhando a obra da morte bem no rosto.

Hegel, dessa maneira, opõe-se menos àqueles que "recuam" do que àqueles que dizem: "não é nada". Ele parece se distanciar mais daqueles que reagem alegremente.

Insisto, querendo fazer destacar, o mais claramente possível, para além da sua semelhança, a oposição entre a atitude ingênua e a Sabedoria - absoluta - de Hegel. Não estou certo, de fato, de que, entre as duas atitudes, a menos absoluta seja a mais ingênua.

Citarei um exemplo paradoxal de reação alegre diante da obra da morte.

O costume irlandês e galês do "wake" é pouco conhecido, mas ainda podia ser observado no fim do século passado. É o assunto da última obra de Joyce, ${ }^{15}$ Finnegan's Wake, ${ }^{16}$ é o velório de Finnegan (mas a leitura desse romance célebre causa no mínimo mal-estar). No país de Gales, dispunha-se o caixão aberto, em pé, no lugar de

\footnotetext{
${ }^{15}$ Sobre o assunto desse livro obscuro, ver E. Jolas, Élucidation $d u$ monomythe de James Joyce (Critique, julho 1948: 579-595).

${ }^{16} \mathrm{O}$ título do romance de James Joyce é Finnegans Wake, sem o sinal diacrítico, e não Finnegan's Wake, como Bataille o grafa. Finnegan's Wake, com o apóstrofe possessivo inglês é, no entanto, o título da divertidíssima balada celta do século XIX, a que o título de Joyce remete. A balada relata o velório do irlandês Tim Finnegan, que nasceu "para o amor da bebida", e uma manhã, bastante alto ("rather full”), cai de uma escada, e quebra o crânio. Segue-se o velório, sua mulher coloca o corpo do marido na cama, dispondo uma garrafa de whisky na cabeça e um barril de cerveja preta nos pés do morto. Os amigos aparecem, o almoço é servido, os convivas bebem, ocorre muita algazarra. Os convivas brigam, até que um pouco de whisky se espalha sobre o corpo do morto, e os "espíritos" da bebida o devolvem à vida. Ele salta da cama "como um troiano" gritando: "pensaram que eu estava morto". O carregador de tijolos, Finnegan, aparece no capítulo introdutório de Finnegans Wake. É um personagem menor do romance. O episódio que segue de perto o relato da balada celta. Como o personagem da balada, Finnegan cai de uma escada e morre. Segue-se o velório, e a ressureição após o cadáver ser banhado de whisky . É a esse episódio que Bataille se refere. (N. do T.)
} 
honra da casa. O morto era vestido com suas mais belas roupas, coberto com a cartola. Sua família convidava todos os amigos, que tanto mais honravam àquele que os havia deixado quanto mais tempo dançassem e bebessem desbragadamente à sua saúde. Trata-se da morte de um outro, mas em tais casos, a morte do outro é sempre a imagem de sua própria morte. Ninguém poderia se regozijar assim a não ser com uma condição; o morto, que é um outro, estando supostamente de acordo, o morto que o beberrão será na sua hora não terá um sentido diferente do primeiro.

Essa reação paradoxal poderia responder ao anseio de negar a existência da morte. Anseio lógico? Creio que não é nada disso. No México, em nossos dias, é comum encarar a morte no mesmo plano que o divertimento: vê-se nela, nas festas, fantoches-esqueletos, açucareiros-esqueletos, carrosséis de cavalos-esqueletos, mas a esse costume se liga um culto intenso dos mortos, uma obsessão visível com a morte. ${ }^{17}$

Não se trata, se encaro a morte alegremente, de dizer de minha parte, desviando-me do que me amedronta: "não é nada" ou "é falso". Ao contrário, a alegria, ligada à obra da morte, me dá angústia, ela é acentuada pela minha angústia e exaspera essa angústia em contrapartida: finalmente, a angústia alegre, a alegria angustiada me proporcionam, num quente-frio, o "absoluto dilaceramento", onde é a minha alegria que acaba de me dilacerar, mas onde o abatimento acompanharia a alegria se eu não estivesse dilacerado até o fim, sem medida.

Gostaria de tornar sensível uma oposição precisa: de um lado a atitude de Hegel é menos inteira que a da humanidade ingênua, mas isso só faz sentido se virmos, reciprocamente, a atitude ingênua impotente em manter-se sem subterfúgios.

\section{O discurso dá fins úteis ao sacrifício "a posteriori" ["après coup"]}

Liguei o sentido do sacrifício à conduta do Homem uma vez satisfeitas as suas necessidades de animal: o Homem difere do ser natural que ele também é: o gesto de sacrifício é o que ele é humanamente, e o espetáculo do sacrifício torna portanto a sua humanidade manifesta. Liberado da necessidade animal, o homem é sobe-

\footnotetext{
${ }^{17}$ Isso se destacava no documentário que Eisenstein retirou de seu trabalho para um filme longo: Tempestade sobre o México. O essencial incidia sobre as bizarrices de que falo.
} 
rano: faz o que lhe apraz, a seu bel prazer. Ele pode fazer enfim nessas condiçóes um gesto rigorosamente autônomo. Enquanto tivesse que satisfazer necessidades animais, ele precisava agir com vistas a um fim (ele devia prover-se de alimentos, proteger-se do frio). Isso supóe uma servidão, uma sequência de atos subordinados ao resultado final: a satisfação natural, animal, sem a qual o Homem propriamente dito, o Homem soberano, não poderia subsistir. Mas a inteligência, o pensamento discursivo do Homem se desenvolveram em função do trabalho servil. Só a palavra sagrada, poética, limitada ao plano da beleza impotente, conservava o poder de manifestar a plena soberania. O sacrifício só é portanto uma maneira de ser soberana, autônoma, na medida em que o discurso significativo não o informa. $\mathrm{Na}$ medida em que o discurso o informa, o que é soberano é dado em termos de servidão. De fato, o que é soberano, por definição, não serve. Mas o simples discurso deve responder à questão colocada pelo pensamento discursivo no tocante ao sentido que cada coisa deve ter no plano da utilidade. Em princípio, ela está ali para servir a tal ou qual fim. Assim, a simples manifestação do liame do Homem com o aniquilamento, a pura revelação do Homem a si mesmo (no momento em que a morte fixa a sua atençáo) passa da soberania ao primado dos fins servis. $\mathrm{O}$ mito, associado ao rito, teve inicialmente a beleza impotente da poesia, mas o discurso em torno do sacrifício deslizou para a interpretação vulgar, interessada. A partir de efeitos ingenuamente imaginados no plano da poesia, como o apaziguamento de um deus, ou a pureza dos seres, o discurso significativo deu como fim da operação a abundância da chuva ou a felicidade da cidade. A volumosa obra de Frazer, que evoca as mais impotentes formas de soberanias e, segundo a aparência, as menos propícias à felicidade, tende a reduzir geralmente o sentido do ato ritual aos mesmos fins do trabalho nos campos, fazendo do sacrifício um rito agrário. Hoje, essa tese do Ramo de ouro está desacreditada, mas ela pareceu sensata na medida em que os próprios povos que sacrificavam inscreveram o sacrifício soberano no âmbito de uma linguagem de lavradores. De fato, de uma maneira bastante arbitrária, que nunca justificou o crédito de uma razão rigorosa, esses povos tentaram, e tiveram que se esforçar para submeter o sacrifício às leis da ação, às quais eles próprios estavam submetidos, ou se esforçavam por se submeter. 
Assim, a soberania do sacrifício também não é absoluta. Ela não o é na medida em que a instituição mantém em um mundo da atividade eficaz uma forma cujo sentido é ser, ao contrário, soberana. Um deslizamento não pode deixar de se produzir, em proveito da servidão.

Se a atitude do Sábio (de Hegel) não é soberana, por sua vez, as coisas se passam no mínimo no sentido contrário: Hegel não se distanciou da soberania autêntica e, se não pôde encontrá-la, aproximou-se dela o mais que podia. O que o separou dela seria mesmo insensível, se não pudéssemos entrever uma imagem mais rica através dessas alteraçóes de sentido, que atingem o sacrifício e o reduziram do estado de fim ao de simples meio. O que, do lado do Sábio, é a chave de um rigor menor é o fato, não de que o discurso engaje a sua soberania em um quadro que náo pode lhe convir e o atrofie, mas precisamente o fato contrário: a soberania na atitude de Hegel procede de um movimento que o discurso revela e que, no espírito do Sábio, nunca é separado de sua revelação. Ela não pode portanto ser plenamente soberana: o Sábio de fato não pode deixar de subordiná-la ao fim de uma Sabedoria supondo o acabamento [achèvement] do discurso. Apenas a Sabedoria será a plena autonomia, a soberania do ser... Ela o seria ao menos se pudéssemos encontrar a soberania buscando-a: de fato, se a busco, faço o projeto de ser - soberanamente: mas o projeto de ser - soberanamente supóe um ser servil! $\mathrm{O}$ que assegura no entanto a soberania do momento descrito é o "dilaceramento absoluto" de que fala Hegel, a ruptura, por um tempo, do discurso. Mas mesmo essa ruptura não é soberana. É em um certo sentido um acidente na ascensão. Embora ambas as soberanias, a ingênua e a sábia, sejam as da morte, fora a diferença de um declínio no nascimento (da lenta alteração à manifestação imperfeita), elas diferem ainda nesse ponto preciso: do lado de Hegel, trata-se justamente de um acidente. Não é um acaso, uma má sorte, que seriam desprovidos de sentido. O dilaceramento, ao contrário, é pleno de sentido. ("O espirito só obtém sua verdade, diz Hegel (mas sou eu que sublinho), quando se encontra no dilaceramento absoluto.") Mas esse sentido é infeliz. Foi o que limitou e empobreceu a revelação que o Sábio tirou de uma estadia nos lugares em que reina a morte. Ele acolheu a soberania como um peso, e o largou... 
Teria eu a intenção de minimizar a atitude de Hegel? Mas é o contrário que é verdadeiro! Quis mostrar o incomparável alcance de seu procedimento. Eu náo devia, para esse fim, velar a parte fraca (e mesmo inevitável) do fracasso.

Para mim, é sobretudo a excepcional segurança desse procedimento que se destaca de minhas aproximaçóes. Se ele fracassou, não se pode dizer que foi o resultado de um erro. $O$ próprio sentido do fracasso difere do do erro que o causou: apenas o erro é talvez fortuito. É geralmente, como de um movimento autêntico e grave de sentido, que se deve falar do "fracasso" de Hegel.

Na verdade, o homem está sempre perseguindo uma soberania autêntica. Essa soberania, segundo a aparência, ele a teve em certo sentido inicialmente, mas sem nenhuma dúvida, não poderia entáo ser de maneira consciente, de modo que em um certo sentido ele não a teve, ela lhe escapou. Veremos que ele perseguiu de várias maneiras o que se lhe esquivava sempre. $\mathrm{O}$ essencial sendo que não se pode atingi-lo conscientemente e buscá-lo, pois a busca o distancia. Mas posso acreditar que nunca nada nos é dado senão dessa maneira equívoca. 